\title{
River water qualities and types of agricultural production -a comparison between paddy farming and intensive livestock production areas
}

\author{
S.-I. Mishima \\ Natural Resources Inventory Centre, \\ National Institute for Agro-Environmental Sciences, Japan
}

\begin{abstract}
The nitrogen $(\mathrm{N})$ flows in the Omoigawa and Nakagawa river basins in Tochigi prefecture, central Japan, in 2000 have been estimated. Omoigawa was characterized as a paddy rice - upland field area and Nakagawa as an intensive livestock farming area. Residual $\mathrm{N}$ caused by agricultural production in Omoigawa was caused mainly by chemical fertilizer application and that in Nakagawa by livestock excreta. Residual $\mathrm{N}$ from agricultural production per farmland area was the same (c. $110 \mathrm{~kg} \mathrm{~N} \mathrm{ha}^{-1}$ ), and occupation of farmland was also the same (c. 20\%). Because Omoigawa is a smaller river basin than Nakagawa, total residual $\mathrm{N}$ in Omoigawa was 2,093 $\mathrm{Mg}$ and that in Nakagawa was 2,469 Mg. Nitrogen flow in river water was divided into sewage-derived $\mathrm{N}$ and non-point-source-derived $\mathrm{N}$, mainly from agricultural production. Nonpoint-source $\mathrm{N}$ in Omoigawa was $2,467 \mathrm{Mg}$ and that in Nakagawa was 1,426 $\mathrm{Mg}$, in spite of the smaller residual $\mathrm{N}$ in Omoigawa. This difference might be caused by differences in sources of residual $\mathrm{N}$ in each basin, and chemicalfertilizer-derived $\mathrm{N}$ might be more easily leached to the water environment than livestock-excreta-derived $\mathrm{N}$. This difference should be considered in vulnerability assessments of water environments. However, livestock excreta $\mathrm{N}$ will eventually leach out too, so intensive livestock farming cannot be said to have a lower effect on water environments and be more sustainable than chemical-fertilizer-dependent agriculture. Increasing sustainability and reducing impacts will help achieve complete $\mathrm{N}$ cycling in river basins with minimal $\mathrm{N}$ input from outside.
\end{abstract}

Keywords: agriculture, nitrogen cycling, nitrogen surplus, river water. 


\section{Introduction}

Appropriate nutrient use is essential for sustainable agricultural production. However, excessive agricultural $\mathrm{N}$ use causes various environmental problems, such as acidification and eutriphication of water and terrestrial environments. The OECD set the soil surface balance as the method to evaluate substantial of nutrient use and $\mathrm{N}$ surplus (or deficiency) as an agro-environmental indicator of the impact or sustainability of agriculture [1]. Although it also set the $\mathrm{N}$ concentration in infiltrated water as a water quality indicator (calculated as $\mathrm{N}$ surplus divided by water surplus [precipitation - evapo-transpiration]) [1], the relationship between $\mathrm{N}$ concentration in infiltrated water and the real contamination or eutriphication of ground and surface water is unclear. Hatano [2] related the ratio of farmland in catchments to $\mathrm{N}$ concentration of river water in grassland farming area in Japan. Nishio [3] calculated $\mathrm{N}$ load indices for each kind of crop in Japan and found a correlation between the sum of $\mathrm{N}$ load indices divided by region area and ground water $\mathrm{N}$ concentration in one prefecture. These reports indicate that contemporary agriculture already affects water environments in Japan. However, the relationship between river water quality and agricultural production structure in a river basin has not been reported. In this study, the relationship between amount of river water $\mathrm{N}$ and $\mathrm{N}$ surplus in 2 mid-scale river basins with different agricultural structures, and thus different causes of $\mathrm{N}$ surplus have been examined.

Table 1: $\quad$ Outline of the river basins.

\begin{tabular}{|c|c|c|c|c|c|}
\hline \multirow{2}{*}{ Total area (ha) } & \multicolumn{2}{|c|}{ Omoigawa } & \multicolumn{2}{|c|}{ Nakagawa } & \multirow{2}{*}{$\begin{array}{r}\text { Japan } \\
37,788,025\end{array}$} \\
\hline & 92,800 & & 123,090 & & \\
\hline Population & 532,502 & & 205,125 & & $126,926,000$ \\
\hline & Area (ha) & Ratio & Area (ha) & Ratio & Ratio \\
\hline Farmland & 19,030 & & 23,273 & & \\
\hline Plantec & 16,048 & $100 \%$ & 21,475 & $100 \%$ & $100 \%$ \\
\hline Paddy fi & 11,289 & $70 \%$ & 12,478 & $58 \%$ & $55 \%$ \\
\hline Upland fie & 4,122 & $26 \%$ & 3,768 & $18 \%$ & $25 \%$ \\
\hline Orch & 432 & $3 \%$ & 128 & $1 \%$ & $7 \%$ \\
\hline Forag & 205 & $1 \%$ & 5,101 & $24 \%$ & $13 \%$ \\
\hline & Head & $\mathrm{Head} \mathrm{ha}^{-1}$ & Head & Head ha ${ }^{-1}$ & Head ha ${ }^{-1}$ \\
\hline Dairy & 5,737 & 0.36 & 33,960 & 1.58 & 0.38 \\
\hline Beef cattle & 14,808 & 0.92 & 23,969 & 1.12 & 0.58 \\
\hline Pigs & 37,654 & 2.35 & 87,673 & 4.08 & 2.00 \\
\hline Layers & 1,665 & 0.10 & 706,250 & 32.89 & 38.67 \\
\hline Broilers & 471 & 0.03 & 13,839 & 0.64 & 6.00 \\
\hline
\end{tabular}




\section{Sites and estimation of $\mathbf{N}$ flows}

The Omoigawa River basin and the upper Nakagawa River basin, in Tochigi prefecture, central Japan have been studied. Statistical and estimated data of these basins are listed in Table 1 [4]. Occupation of farmland is c. $20 \%$ in both basins, although the agricultural production structures are different. In Omoigawa, livestock density is near the Japanese average and occupation of paddy fields is higher than the Japanese average. The remaining farmland is vegetable fields and orchards. Therefore, Omoigawa could be defined as a paddy farming area. In contrast, the livestock density of Nakagawa is 2 to 4 times the Japanese average, and c. $20 \%$ of farms grows forage for dairy and beef cattle. Therefore, Nakagawa could be defined as an intensive livestock farming area.

Models of $\mathrm{N}$ flow in the river basins are shown in Figure 1. Data were sourced and estimated according to Mishima et al. [5], except for sewage discharge, leaching, and river water N. Raw sewage discharge was set as $12.0 \mathrm{~g}$ $\mathrm{N}$ day $^{-1}$ per capita and $\mathrm{N}$ removal by sewage treatment as $49 \%$ [6]. River water flows and their $\mathrm{N}$ concentrations came from a river water quality database [7] for Omoigawa and the River Water Yearbook [8] for Nakagawa.

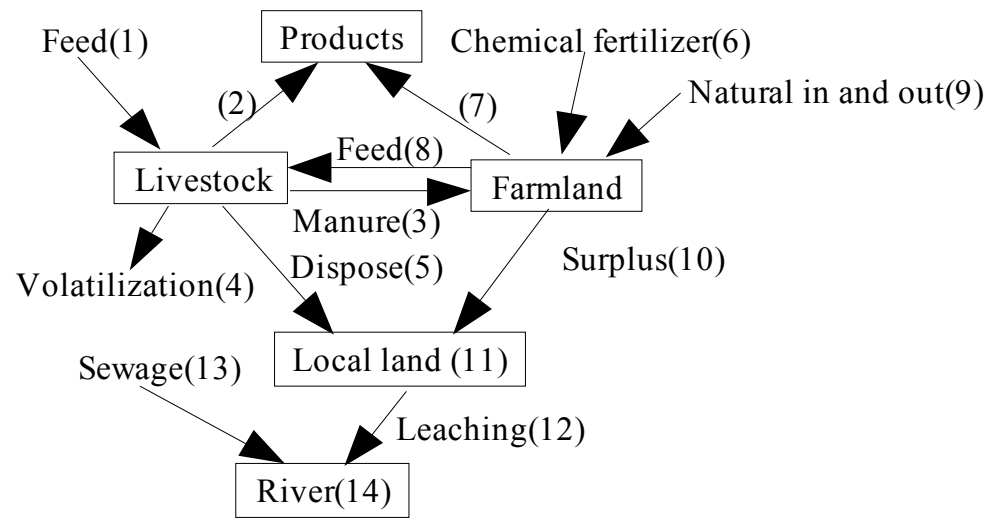

Figure 1: Model of $\mathrm{N}$ flow in the river basin.

\section{Results and discussions}

\subsection{Nitrogen flows in river basins}

The results are indicated in Table 2. In Nakagawa, $\mathrm{N}$ in livestock product (80.4 $\mathrm{kg} \mathrm{N} \mathrm{ha}{ }^{-1}$ ) was nearly 3 times that in Omoigawa $\left(27.6 \mathrm{~kg} \mathrm{~N} \mathrm{ha}^{-1}\right)$. This emphasizes that Nakagawa is an intensive livestock production area, where production was sustained by $58.6 \mathrm{~kg} \mathrm{~N} \mathrm{ha}^{-1}$ of feed produced in the basin and $275.0 \mathrm{~kg} \mathrm{~N} \mathrm{ha}^{-1}$ imported from outside. Although livestock manure containing $55.0 \mathrm{~kg} \mathrm{~N} \mathrm{ha}{ }^{-1}$ was applied to farmland for crop production, more livestock 
Table 2: $\quad$ Nitrogen flows in the model.

\begin{tabular}{|c|c|c|c|c|}
\hline & \multicolumn{2}{|c|}{ Omoigawa } & \multicolumn{2}{|c|}{ Nakagawa } \\
\hline & $\mathrm{Mg} \mathrm{N}$ & $\mathrm{kg} \mathrm{N} \mathrm{ha}^{-1}$ & $\mathrm{Mg} \mathrm{N}$ & $\mathrm{kg} \mathrm{N} \mathrm{ha}^{-1}$ \\
\hline \multicolumn{5}{|l|}{ Livestock } \\
\hline Feed (1) & 2,180 & 114.6 & 6,400 & 275.0 \\
\hline Product (2) & 526 & 27.6 & 1,870 & 80.4 \\
\hline Manure (3) & 503 & 26.4 & 1,281 & 55.0 \\
\hline Volatilization (4) & 738 & 38.8 & 2,395 & 102.9 \\
\hline Disposal (5) & 532 & 28.0 & 1,683 & 72.3 \\
\hline Farmland & & 0.0 & & 0.0 \\
\hline Chemical fertilizer (6) & 1,817 & 95.5 & 1,686 & 72.4 \\
\hline Product (7) & 922 & 48.4 & 975 & 41.9 \\
\hline Feed (8) & 88 & 4.6 & 1,364 & 58.6 \\
\hline Natural in and out (9) & 99 & 5.2 & 156 & 6.7 \\
\hline Surplus (10) & 1,561 & 82.0 & 785 & 33.7 \\
\hline Local land(11) & 2,093 & 110.0 & 2,469 & 106.1 \\
\hline Leaching $(12)=(14)-(13)$ & 2,467 & & 1,426 & \\
\hline Sewage (13) & 1,190 & & 458 & \\
\hline River (14) & 3,657 & & 1,884 & \\
\hline
\end{tabular}

excreta was disposed of to local land $\left(72.3 \mathrm{~kg} \mathrm{~N} \mathrm{ha}^{-1}\right)$. How to use or treat all livestock excreta is a common problem in intensive livestock production areas in Japan. In Omoigawa, manure application to farmland contained $26.4 \mathrm{~kg} \mathrm{~N}^{-1}$ and feed production for livestock contained $4.6 \mathrm{~kg} \mathrm{~N} \mathrm{ha}^{-1}$, so $\mathrm{N}$ exchange between livestock and farmland was not as active as in Nakagawa. This was a result of the smaller livestock production and low occupation of forage fields. On the other hand, chemical fertilizer application was larger in Omoigawa $(95.5 \mathrm{~kg}$ $\mathrm{N} \mathrm{ha}{ }^{-1}$ ) than in Nakagawa $\left(72.4 \mathrm{~kg} \mathrm{~N} \mathrm{ha}^{-1}\right)$. This difference resulted from the difference in planted crops. Although paddy fields are dominant in both basins, upland field crops differ. Omoigawa has more areas of vegetable fields, which receive more chemical fertilizer than in Nakagawa, and occupation of upland fields in Nakagawa is smaller than in Omoigawa. Natural $\mathrm{N}$ input and output are the same in both basins. Crop production for shipment outside the basin was $15 \%$ larger in Omoigawa (48.4 $\mathrm{kg} \mathrm{N} \mathrm{ha}^{-1}$ ) than in Nakagawa (41.9 $\mathrm{kg} \mathrm{N} \mathrm{ha}^{-1}$ ), although the difference is small and the values might be said to be the same, total productivity in each basin was different. Total $\mathrm{N}$ input by chemical fertilizer and manure was $121.9 \mathrm{~kg} \mathrm{~N}^{-1}$ and total crop production was $53.0 \mathrm{~kg} \mathrm{~N}^{-1}$ in Omoigawa, vs. $127.4 \mathrm{~kg} \mathrm{~N}^{-1}$ and $100.5 \mathrm{~kg} \mathrm{~N} \mathrm{~h}^{-1}$ in Nakagawa. Therefore, the $\mathrm{N}$ input in both basins was the same, but total crop production was c. 2 times as large in Nakagawa. This difference was caused by forage production, which has higher productivity per area than other crops. As the result of the higher production, the $\mathrm{N}$ surplus on farmland in Nakagawa $\left(33.7 \mathrm{~kg} \mathrm{~N} \mathrm{~h}^{-1}\right.$ ) was lower than that in Omoigawa $\left(82.0 \mathrm{~kg} \mathrm{~N} \mathrm{ha}^{-1}\right)$. Livestock production was smaller in 
Omoigawa than in Nakagawa, so disposal of livestock excreta $\left(28.0 \mathrm{~kg} \mathrm{~N} \mathrm{ha}^{-1}\right)$ was c. $1 / 3$ of that in Nakagawa, but disposal was larger than manure use. Residual $\mathrm{N}$ in agricultural production (i.e. disposal of livestock excreta plus surplus $\mathrm{N}$ on farmland) was $110.0 \mathrm{~kg} \mathrm{~N} \mathrm{ha}^{-1}$ in Omoigawa and $106.1 \mathrm{~kg} \mathrm{~N}^{-1}$ in Nakagawa. This residual $\mathrm{N}$ is loaded onto local land.

\subsection{Nitrogen flow in river water and $\mathrm{N}$ load to local land}

The amount of $\mathrm{N}$ flow in river water on average from 1989 to 1999 was estimated to be 2 times as large in Omoigawa (3657 $\mathrm{Mg} \mathrm{N}$ year ${ }^{-1}$ ) than in Nakagawa (1884 Mg N year ${ }^{-1}$ ) because of the higher $\mathrm{N}$ concentration in Omoigawa water $\left(2.5-5.1 \mathrm{mg} \mathrm{N} \mathrm{L}^{-1} ; 964 \mathrm{Tg}^{-1}\right.$ water year $\left.{ }^{-1}\right)$ than in Nakagawa water (1.28-1.83 $\mathrm{mg} \mathrm{N} \mathrm{L}^{-1} ; 1194 \mathrm{Tg}$ water year ${ }^{-1}$ ). Sewage discharge to the river was estimated as $1190 \mathrm{Mg} \mathrm{N}$ year $^{-1}$ in Omoigawa and $458 \mathrm{Mg} \mathrm{N}_{\text {year }}{ }^{-1}$ in Nakagawa. This difference came from the difference in population in the river basins. The remaining $\mathrm{N}$ in river water came from local land in the basin, mainly as residual $\mathrm{N}$ from agricultural production, because the natural ecosystem is basically $\mathrm{N}$ limiting, so $\mathrm{N}$ discharge (i.e. background level) is very low. Nitrogen leaching from local land was $2467 \mathrm{Mg} \mathrm{N}$ year $^{-1}$ in Omoigawa and $1426 \mathrm{Mg} \mathrm{N}$ year $^{-1}$ in Nakagawa. Residual $\mathrm{N}$ from agricultural production was $2093 \mathrm{Mg} \mathrm{N}$ in Omoigawa, less than the estimated $\mathrm{N}$ leaching from local land. This result might be caused by the high $\mathrm{N}$ removal rate by sewage treatment or leaching of past high $\mathrm{N}$ application before 2000. For example, $\mathrm{N}$ application for paddy rice in Tochigi prefecture has reduced over the past 2 decades by c. $30 \%$. On the other hand, only $58 \%$ of residual $\mathrm{N}$ load to local land (i.e. (12)/(11)) leached to the river. The rest would accumulate in local land, at least for now. The $\mathrm{N}$ load to the river from agriculture is larger in Omoigawa than in Nakagawa. The difference might be caused by differences in the causes of residual N. In Omoigawa, N surplus on farmland (1561 Mg N) was c. 3 times the disposal of livestock excreta $(532 \mathrm{Mg} \mathrm{N})$, and was caused by a large application of chemical fertilizer (1817 $\mathrm{Mg} \mathrm{N}$ ), because the natural input/output of $\mathrm{N}$ plus manure application (602 $\mathrm{Mg}$ N) was $1 / 3$ of chemical fertilizer. Therefore, the $N$ load to local land in the Omoigawa River basin can characterized as chemical-fertilizer-derived N. On the other hand, the disposal of livestock excreta $(1683 \mathrm{Mg} \mathrm{N})$ was 2 times the $\mathrm{N}$ surplus on farmland ( $785 \mathrm{Mg} \mathrm{N}$ ) in Nakagawa, and farmland received more than twice as much livestock manure (1281 Mg N; $\left.55 \mathrm{~kg} \mathrm{~N} \mathrm{ha}^{-1}\right)$ than in Omoigawa (503 Mg; $26 \mathrm{~kg} \mathrm{~N} \mathrm{ha}^{-1}$ ). Livestock manure $(1281 \mathrm{Mg}$ ) was $3 / 4$ of chemical fertilizer application (1686 Mg N), so the proportion of manure-derived $\mathrm{N}$ in surplus would be larger than in Omoigawa. Therefore, the $\mathrm{N}$ load to local land in the Nakagawa River basin can be characterized as livestock-excreta-derived $\mathrm{N}$. This difference in sources of $\mathrm{N}$ load might cause differences in $\mathrm{N}$ leaching from local land to river, as chemical-fertilizer-derived $\mathrm{N}$ is relatively easier to leach out than livestock-excreta-derived-N. Although farmland soil can accumulate organic matter including $\mathrm{N}$, the $\mathrm{N}$ eventually becomes mineralized and starts to leach out. Maeda et al. [9] found that $\mathrm{N}$ leach-out from soils treated with chemical fertilizer or swine manure became the same after 4 years when $\mathrm{N}$ application in swine manure was twice that in chemical fertilizer. This result 
might suggest that leaching of manure-derived $\mathrm{N}$ will be less than that of fertilizer-derived $\mathrm{N}$, but accumulated $\mathrm{N}$ will leach out later. Therefore, it will be too late to do anything when an increase in $\mathrm{N}$ concentration in river water becomes apparent. Figure 2 indicates the dynamics of the number of livestock in the Nakagawa River basin in the last 50 years. Although broilers have been decreasing, dairy and beef cattle numbers have doubled in the last 20 years, and pig numbers have doubled in the last 10 years. This increase in intensive livestock farming could presage a large increase in $\mathrm{N}$ leaching from manure applied to farmland or loaded onto local land.

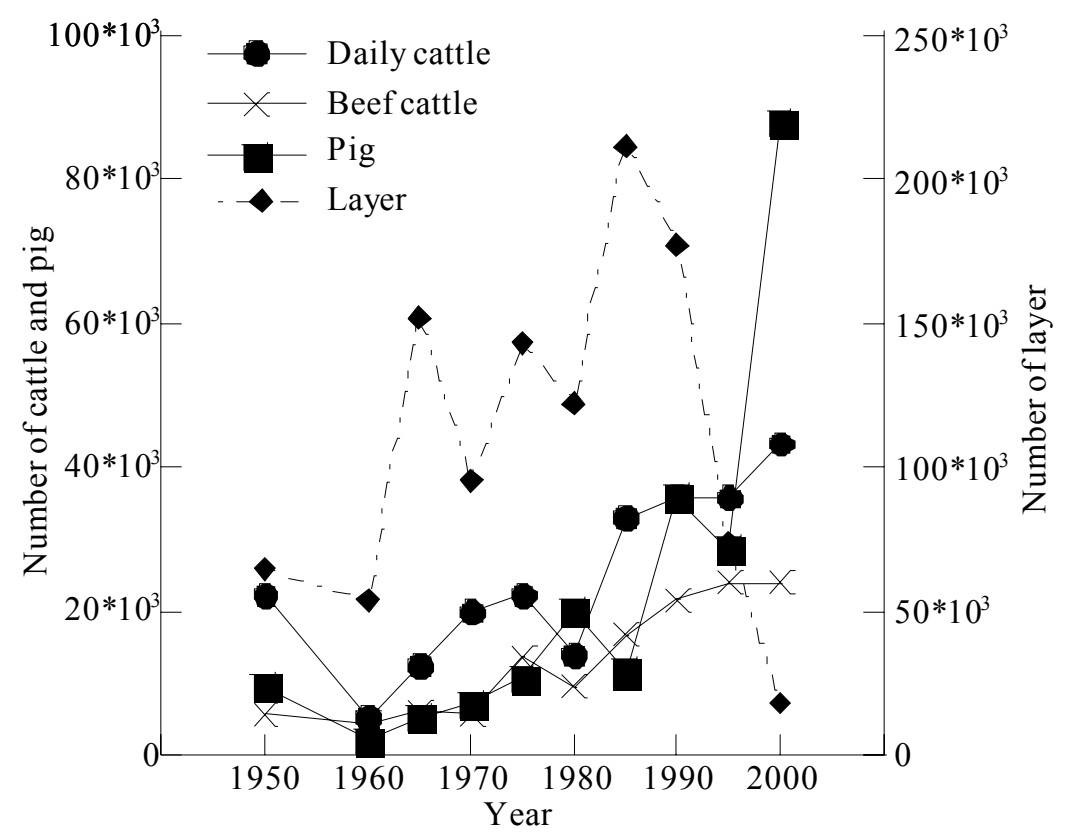

Figure 2: Growth of livestock numbers in Nakagawa.

\section{3 $\mathrm{N}$ application: vulnerability and possible mitigation methods}

The risk of $\mathrm{N}$ leaching from livestock excreta might be lower than that of leaching from chemical fertilizer if Maeda et al.'s results [9] can be substantiated. However, broad scale and substantial $\mathrm{N}$ reuse will reduce environmental impacts, and help achieve sustainable agriculture. In Omoigawa, excessive chemical fertilizer is applied: for example, $56 \mathrm{~kg} \mathrm{~N} \mathrm{ha}^{-1}$ is applied on strawberries, although guidelines recommend $20 \mathrm{~kg} \mathrm{~N} \mathrm{ha}^{-1}$. Therefore, complying with fertilizer guidelines can reduce chemical fertilizer application. Manure used in Nakagawa comes from outside the basin. The use of local manure in forage production, expansion of forage area, and an increase in selfsufficient feed would mitigate leaching, and limiting livestock numbers would 
contribute to healthy and sustainable $\mathrm{N}$ cycling within river basins. However, an appropriate level of manure $\mathrm{N}$ application remains an open question. However, fertilizer guidelines are aimed at achieving crop yields or maintaining high soil fertility, not at having a low environmental impact. To assess this we would need to use mathematical models of $\mathrm{N}$ mineralization and leaching, such as Roth $\mathrm{N}$ and Soil N, or develop site-specific models and set new standards for livestock excreta application.

\section{Conclusion}

Woli et al. [10] regressed $\mathrm{N}$ surplus and occupation of farmland area and found a significant relationship between the regression coefficient (which they called an "impact factor") and river water $\mathrm{N}$ concentration. In this study, although Omoigawa and Nakagawa had the same farmland occupation and residual $\mathrm{N}$, the $\mathrm{N}$ concentration in river water caused by non-point sources, mainly agricultural production was 1.7 times as large in Omoigawa as in Nakagawa. But delay of leaching between chemical fertilizer and livestock manure will have an effect on the evaluation and delineation of vulnerable areas, and large uncertainty in $\mathrm{N}$ dynamics remains. Which basin is more sustainable cannot be concluded, even though $\mathrm{N}$ flow in Nakagawa is lower than in Omoigawa, because a huge amount of livestock excreta is disposed of. Livestock excreta should be completely consumed on farmland within each basin and chemical fertilizer usage should be reduced to the minimum needed. Continuous monitoring of soil $\mathrm{N}$ content, $\mathrm{N}$ availability, and $\mathrm{N}$ concentration in groundwater will be needed. Such monitoring would support low-impact, sustainable agriculture and management of river basin agriculture. The ideal sustainable agricultural production system would isolate the $\mathrm{N}$ cycle within a river basin and minimize $\mathrm{N}$ input from outside. However, such agriculture might reduce yields, so it would be necessary to balance sustainability against productivity.

\section{References}

[1] OECD, Environmental Indicators for Agriculture, pp. 24-35, 1999.

[2] Hatano R., Evaluation of nitrogen cycling in river basin by measuring nitrogen outflow to river. Sequel to predicting environmental load, ed. R. Hatano \& K. Inubushi, Hakuyusha, Tokyo, pp. 43-59, 2005.

[3] Nishio, M., Analysis of the actual state of nitrogen application in an arable farming in Japan. Japanese Journal of Soil Science and Plant Nutrition, 72(4), pp. 513-521, 2001.

[4] Kanto Nosei Kyoku, Tochigi prefecture Agricultural Census 2000 CDROM, Ministry of Agriculture, Forestry and Fisheries, Tokyo, 2001.

[5] Mishima, S., Taniguchi, S. \& Komada, M., Adaptation of life cycle assessment (LCA) to agricultural production on a regional scale in Japan. Ecosystems and Sustainable Development V, ed. E. Tiezzi, C.A. Brebbia, S.E. Jorgensen \& D.A. Gomar, WIT Press, Southampton, pp. 671-678, 2005. 
[6] Kunimatsu, T. \& Muraoka, H., Model Analysis of River Water Contamination, Gihodo Press, Tokyo, pp. 12-14, 1989.

[7] RPWQM, http://www-gis.nies.go.jp/intro/intro.html

[8] River Association Japan, River Water Quality Yearbook, p. 340, Tokyo, 2001.

[9] Maeda, M., Zhso, B., Ozaki, Y. \& Yoneyama, T., Nitrate leaching in an Andisol treated with different types of fertilizers. Environmental Pollution, 121, pp. 477-487, 2003.

[10] Woli, K.P., Nagumo, T., Kuramochi, K. \& Hatano, R., Evaluating river water quality through land use analysis and $\mathrm{N}$ budget approaches in livestock farming areas. Science of Total Environment, 329, pp. 61-74, 2004. 